\title{
Improving the Nitrogen Mineralization of Dried Azolla pinnata as a Bio-fertilizer for Increased Rice Production in the Vertisol
}

\author{
S. Asuming-Brempong*, N. K. Amon and V. Adusei-Okrah \\ Department of Soil Science, University of Ghana, Legon \\ *Corresponding author
}

\begin{abstract}
An incubation experiment was conducted to improve the rate of nitrogen mineralization of dried Azolla pinnata samples in the Akuse series of the Vertisol. Incubation was done for 60 days at soil moisture content of $40 \%$ and at room temperature of $28{ }^{\circ} \mathrm{C}$. The available $\mathrm{N}$ (ammonium and nitrate $\mathrm{N}$ ) was determined for each of the treatment samples on every tenth day after incubation by extracting soil sample with $1 M \mathrm{KCl}$. The treatments were fresh azolla (FA), dry azolla (DA), dry azolla + urea (DA+U), pelleted dry azolla + urea (PDA+U) and the control (C), where neither azolla nor nitrogen fertilizer was applied. From 10 to 30 days after incubation, immobilization of nitrate $\mathrm{N}$ was observed for the treatments DA and PDA+U. Mineralization was highest for PDA+U treatment and the least for the DA treatment between 40-60 days after incubation. The addition to pelleted dried azolla of $3 \mu \mathrm{g} / \mathrm{g}$ urea fertilizer improved the nitrogen mineralization.
\end{abstract}

\section{Introduction}

The availability of nitrogen is vital in the production of rice to ensure high grain yields. With the continual rise in the cost of chemical fertilizer and the introduction of high yielding rice varieties that require higher nitrogen levels, the resource poor farmers have difficulty in accessing and utilizing the recommended application rates of fertilizer for rice production. The introduction and the use of cheaper and easily available forms of biofertilizer such as azolla will be of great benefit to such rice farmers.

Azolla is a genus of Leptosporangiate, an aquatic fern that harbours a heterocyst-forming, nitrogenfixing blue-green alga, Anabaena azollae as a symbiont in the dorsal lobe cavity (Peters \& Mayne, 1974). Atmospheric nitrogen fixed by the symbiont can fulfill the nitrogen requirement of the association (Peters et al., 1980), and supplement the nitrogen needs of rice when azolla is grown as a green manure. Azolla can fix about $1.1 \mathrm{~kg} \mathrm{~N} / \mathrm{ha} /$ day when used as a green manure, and in 30 days, under favourable environmental condition, about $30 \mathrm{~kg} \mathrm{~N} / \mathrm{ha}$ would have been fixed. Apart from azolla being used as a green manure for rice and other such crops, it significantly improves the soil organic carbon content, thus, sequestering carbon in soils (Ramesh \& Chandrasekaran, 2004).

While the positive effects of fresh azolla on rice yield and soil physical properties are well demonstrated, little is known of the use of dried azolla in Ghana, thus, indicating that the full potential of azolla as a biofertilizer in rice production in this country has not yet been realized. Such dried azolla can be available all year round. The growth of azolla in the tropics is best during the rainy season when the productivity is high. Low productivity of azolla occurs in the dry season. High environmental temperature during the dry season induces increased insect infestation and fungal infection on azolla, as well as excessive blooming of free living algae in ponds and lakes (Lumpkin, 1987). These factors and others make it difficult to grow fresh azolla in the dry season, thus, compelling the need to explore the use of dry azolla. Studies conducted by Li et al. (1982) showed that the lignin content of dry azolla was $21 \%$, and this was higher than fresh azolla lignin of $18 \%$, making the mineralization of dried azolla more difficult. The objective of this study was to improve on the $\mathrm{N}$ mineralization status of dried and other similarly treated azolla in the Vertisol.

\section{Soil sampling}

\section{Materials and methods}

The soil was sampled to a depth of $0-15 \mathrm{~cm}$ from an uncultivated field at the University of Ghana Agricultural Research Centre at Kpong. All samples were then cooled on ice and transported to the Soil Science Laboratory of the University of Ghana, where sieving was done with a 2-mm sieve.

West African Journal of Applied Ecology - Volume 13 


\section{Chemical analysis of soil}

Part of the sieved soil was air-dried and some chemical properties were determined.

The $p \mathrm{H}$ of soil was determined using $p \mathrm{H}$ meter with glass-calomel combination electrode in distilled water and $0.01 \mathrm{M} \mathrm{CaCl}_{2}$ solution at a ratio of 1:2 soil:solution. The organic carbon content was determined using the Walkley and Black method (1934). The total nitrogen was determined by the Kjeldahl method whilst the cation exchange capacity (CEC) was determined as described by the method of Thomas (1982). The available phosphorus was determined by the Bray 1 method where $0.03 M \mathrm{NH}_{4} \mathrm{~F}$ in $0.025 \mathrm{M} \mathrm{HCl}$ was used as the extractant, and the colour development was done using the Watanabe and Olsen's method (1965).

Some of the chemical properties of soil and azolla used are shown in Table 1. The soil is classified as the Vertisol (USDA and the FAO classification systems). The organic carbon content of soil was $8.7 \mathrm{~g} / \mathrm{kg}$ soil and the dominant exchangeable cations were $\mathrm{Ca}^{2+}$ and $\mathrm{Mg}^{2+}$ and has low available $\mathrm{P}$ (Table 1). The cation exchange capacity is $43.26 \mathrm{cmol}(+) / \mathrm{kg}$ soil and the base saturation of $82.76 \%$. For the azolla strain used, the C:N ratio was 12.9:1 (Table 1), the relative growth rate was $0.20 \mathrm{~g} / \mathrm{g} / \mathrm{day}$ and the doubling time was 3.06 days.

TABLE 1

Some chemical properties of Akuse series and Azolla pinnata

$\begin{array}{lcc}\text { Property } & \text { Soil (Vertisol) } & \text { Azolla pinnata } \\ & & \\ p \mathrm{H} \text { in water }(1: 2) & 7.58 & \\ p \mathrm{H} \text { in } 0.01 \mathrm{M} \mathrm{CaCl}_{2} \text { solution } & 6.88 & 492.4 \\ \text { Organic carbon } \mathrm{g} / \mathrm{kg} & 8.7 & 38 \\ \text { Total nitrogen } \mathrm{g} / \mathrm{kg} & 6.0 & 12.9: 1 \\ \mathrm{C}: \mathrm{N} & & \\ & & \\ \text { Available phosphorus } \mathrm{mg} / \mathrm{kg} & 0.52 & \\ & & \\ \text { Exchangeable cations }(\mathrm{cmol}(+) / \mathrm{kg} / \mathrm{soil} & & \\ \mathrm{Ca}^{2+} & 23.6 & \\ \mathrm{Mg}^{2+} & 10.6 & \\ \mathrm{~K}^{+} & 0.08 & \\ \mathrm{Na}^{+} & 1.52 & \\ \mathrm{Cation}^{2} \text { exchange capacity }(\mathrm{cmol}(+) / \mathrm{kg} / \mathrm{soil} & 43.26\end{array}$

\section{Azolla collection, preparation and culti-vation}

Azolla pinnata was collected from the Crop Science Department of the University of Ghana, Legon. It was gently washed with tap water and the azolla was dried with tissue paper. The azolla was then cultured using the International Rice Research Institute Medium (IRRI Medium, 1979; Aappendix 1). Fresh Azolla pinnata was weighed and cultured to obtain enough azolla biomass for the experiment. The relative growth rate (RGR) of the fresh azolla was determined by using the following formula

$\mathrm{RGR}=\log _{\mathrm{e}} \mathrm{W}_{2}-\log _{\mathrm{e}} \mathrm{W}_{1} \mathrm{~g} / \mathrm{g} /$ day

$$
\mathrm{t}_{2}-\mathrm{t}_{1}
$$

where $\mathrm{W}_{1}$ and $\mathrm{W}_{2}$ were the dry weight of azolla at times $\mathrm{t}_{1}$ and $\mathrm{t}_{2}$, respectively. Growth of azolla was maintained at the exponential growth phase.

Nitrogen mineralization studies

West African Journal of Applied Ecology - Volume 13 
There were five azolla treatments for the nitrogen mineralization study. These treatments were fresh azolla (FA), dry azolla (DA), dry azolla + urea $(\mathrm{DA}+\mathrm{U})$, pelleted dry azolla + urea $(\mathrm{PDA}+\mathrm{U})$ and for the control (C) no azolla nor mineral $\mathrm{N}$ fertilizer was added to soil sample. Each of these treatments contained total $\mathrm{N}$ of $32.5 \mathrm{mg} \mathrm{N}$ but the PDA+U treatment contained $32.49 \mathrm{mg} \mathrm{N}+0.01 \mathrm{mg}$ urea $\mathrm{N}$. The pelleted azolla was prepared by taking a known amount of dry azolla and mixing with a few drops of starch solution to form pellets. A small hole was made in the pellet and allowed to air-dry for 3 days at room temperature. After that, urea was inserted into it using a spatula and sealed with the rest of the dry azolla.

Thirty grams of sieved soil was put into a black polyethylene bag. The moisture content of the soil was adjusted to $40 \%$ moisture holding capacity, and each of the azolla treatment was incorporated into the soil. The samples were incubated at room tempera-ture in the laboratory at $28{ }^{\circ} \mathrm{C}$ setting them up in a completely randomized design with 21 replicates. Sampling of soil was carried out on days $0,10,20,30$, 40, 50 and 60 of incubation (for each sampling time, replicate treatment was taken for analysis). Soil sample of $10 \mathrm{~g}$ was taken from each treatment after mixing the soil thoroughly in the polyethylene bag and $50 \mathrm{ml}$ of $1 M \mathrm{KCl}$ added to soil in a plastic tube. The tube was capped and shaken for $1 \mathrm{~h}$ on a mechanical shaker and the mixture filtered, using Whatman No. 44 filter paper. The method of Ogoshi et al. (1999) was used to determine both ammonium and nitrate $\mathrm{N}$, using $10 \mathrm{ml}$ of the above filtrate.

\section{Statistical analysis}

The data was subjected to analysis of variance using Genstat software (Rotham-sted Experimental Station, Harpenden, Hertfordshire, UK) and significance of treatment effects, and was tested at the 5\% level of probability. The least significant difference (LSD) was used to separate the means.

\section{Results and discussion}

The ammonium- $\mathrm{N}$ mineralization patterns for the different azolla treatments are shown in Fig. 1. The same pattern of ammonia released was observed for almost all the treatments. Treatment PDA $+U$ had a high release of ammonia on day 20 after incubation. Generally, the amount of ammonium $\mathrm{N}$ released was lower than total nitrate $\mathrm{N}$ released (Fig. 1 and 2). The release pattern of nitrate was low from day 0 to day 30 of incubation. From days 40 to 60 , release of nitrate $\mathrm{N}$ was high, resulting in high total $\mathrm{N}$ released (Fig. 2). On the day 10 to day 30, immobilization of nitrate $\mathrm{N}$ was observed for the dry azolla (DA) and the other treatments.
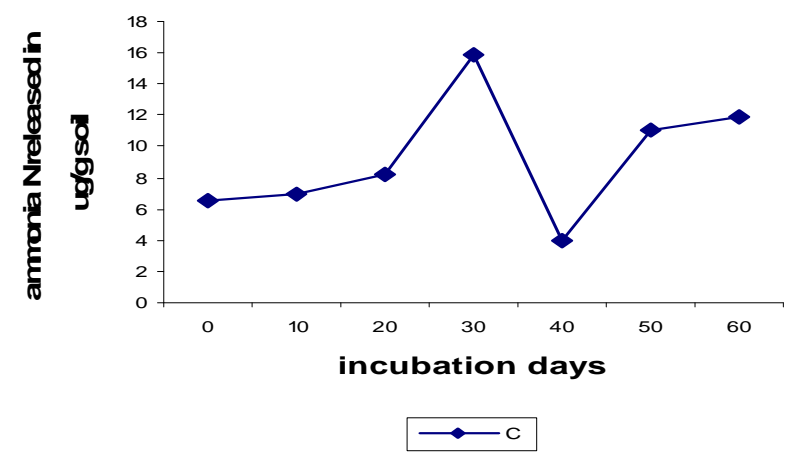

West African Journal of Applied Ecology - Volume 13 

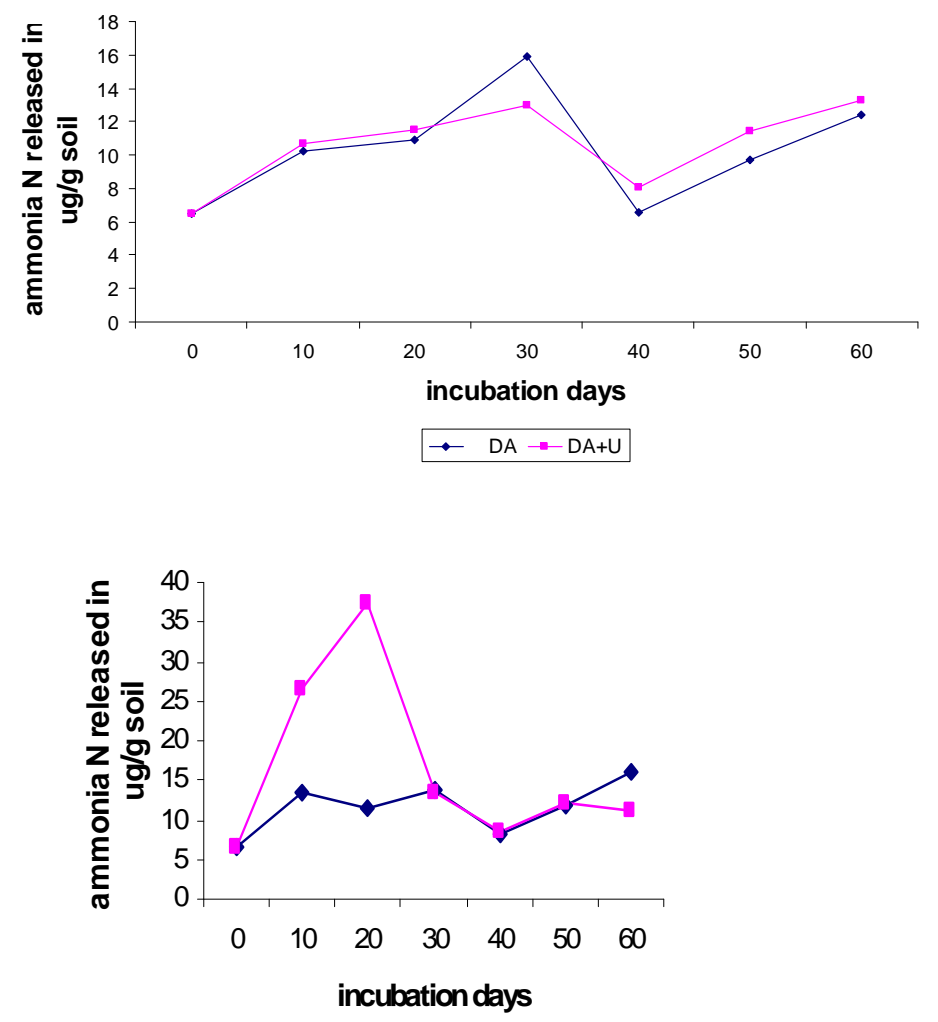

$\rightarrow F A \rightarrow P D A+U$

Fig. 1. Ammonia $\mathrm{N}$ released from differently treated azolla samples in the Akuse series
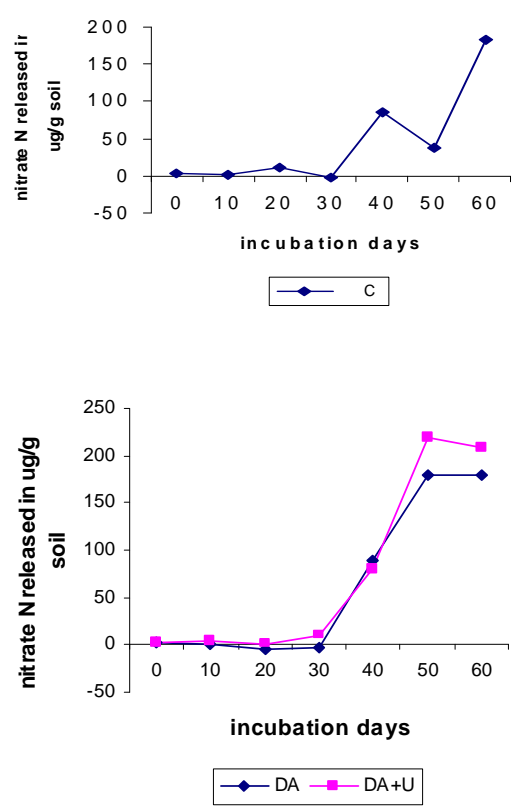

West African Journal of Applied Ecology - Volume 13 


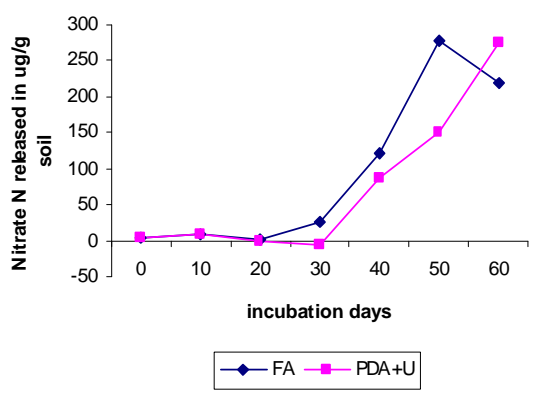

Fig. 2. Nitrate $\mathrm{N}$ released from differently treated azolla samples in the Akuse series

Total $\mathrm{N}$ mineralized from the control was highest on day 60 of incubation (Table 2). Treatment DA had a lower $\mathrm{N}$ mineralized at 20,30 and 60 days as compared to $\mathrm{C}$ even though the difference was not significant. On day 50, $\mathrm{N}$ mineralized in DA was significantly higher than $\mathrm{C}$ (Table 2). Mineralization of DA was improved when urea was added, thus, from day 50, significantly higher mineralization rate was obtained for DA+U than for DA alone (Table 2).

TABLE 2

Total $N$ in $\mu g / g$ soil (ammonium $N+$ nitrate $N$ ) mineralized in different soil treatments

\begin{tabular}{crrrrrr} 
Incubation days & Control & \multicolumn{1}{c}{$D A$} & $D A+U$ & \multicolumn{1}{c}{$F A$} & $P D A+U$ & $L S D(0.05)$ \\
0 & & & & & & \\
10 & 9.20 & 9.20 & 9.20 & 9.20 & 9.20 & 18.82 \\
20 & 7.60 & 11.00 & 15.40 & 21.90 & 36.50 & 24.41 \\
30 & 9.20 & 5.60 & 11.70 & 13.20 & 36.60 & 21.21 \\
40 & 14.00 & 12.20 & 22.20 & 39.80 & 7.80 & 19.59 \\
50 & 90.00 & 95.10 & 88.50 & 129.40 & 94.50 & 21.26 \\
60 & 49.00 & 189.00 & 231.00 & 290.00 & 163.00 & 13.87 \\
$\operatorname{LSD}(0.05)$ & 194.70 & 192.70 & 222.30 & 235.00 & 286.90 & 61.99 \\
& 60.70 & 19.31 & 30.87 & 48.68 & 96.80 &
\end{tabular}

Molding a ball with dried azolla and placing urea in the centre of it, improved significantly the mineralization rate, possibly because of the better contact of urea with the dried azolla. The starch might have contributed to this observation and this could be validated in a later study. Total $\mathrm{N}$ mineralized for $\mathrm{PDA}+\mathrm{U}$ was highest on 60 days of incubation. However, on 30 days of incubation, total $\mathrm{N}$ was very low for the PDA+U treatment. This might be due to the immobilization of nitrate $\mathrm{N}$ at this period. Total $\mathrm{N}$ mineralized for FA was high from day 40 and the highest total $\mathrm{N}$ mineralized was on day 50, where $\mathrm{N}$ mineralized was significantly different from the control. But on day 60 , the total $\mathrm{N}$ mineralized began declining with the FA treatment. A similar observation was made by Watanabe et al. (1977) when within 40-50 days after incorporating fresh azolla in paddy fields, about $60 \%$ of its organic nitrogen had been mineralized. Beyond that period, nitrogen mineralization was low.

Total $\mathrm{N}$ for the soil was $0.06 \%$ (Table 1). It was expected that total $\mathrm{N}$ mineralized in that soil would be around $600 \mu \mathrm{g} \mathrm{N} / \mathrm{g}$ soil but such an observation was not made. Except for the PDA +U and FA treatments, which had total $\mathrm{N}$ mineralized around $220-300 \mu \mathrm{g} \mathrm{N} / \mathrm{g}$ soil, the rest of the treatments had a lower total $\mathrm{N}$ of $<200 \mu \mathrm{g} \mathrm{N} / \mathrm{g}$ soil. Probably some of the ammonia $\mathrm{N}$ released during mineralization was trapped in the lattice layer of the expanding clay of the Akuse series, and the rest lost through volatilization considering the neutrality of the soil $p \mathrm{H}$.

West African Journal of Applied Ecology - Volume 13 
From the study, dry azolla mineralization can be improved when urea fertilizer ( $3 \mu \mathrm{g} / \mathrm{g}$ dry azolla) is added and is even more improved in the pelleted form (PDA+U form). However, the nitrogen in PDA+U becomes more available after 50 days of incorporating in the soil. PDA+U treatment can be used with fresh azolla so that within the first 6 weeks, $\mathrm{N}$ is released from fresh azolla for rice plant use and later, $\mathrm{N}$ released from $\mathrm{PDA}+\mathrm{U}$ treatment.

\title{
Conclusion
}

The mineralization of dry azolla can be improved by molding the azolla in the form of a pellet and introducing small amount of urea fertilizer to the pelleted azolla. High amount of $\mathrm{N}$ is mineralized from days 50 to 60 , and such a bio-fertilizer can be useful to long duration crops, such as long duration lowland rice varieties.

\section{References}

Li Z., Zu S., Mao M. and Lumpkin T. A. (1982). Study on the utilization of eight Azolla species in agriculture.1. An investigation of utilization properties (in Chinese). Sci. Agric. Sin. 1: 19-28.

Lumpkin T. A. (1987). Environmental requirements for successful Azolla growth. In Azolla Utilization. International Rice Research Institute Publication. 296 pp.

Ogoshi R. M., Cagauan B. G., Jr and Tsuji G. Y. (1999). Field and laboratory methods for the collection of the minimum dataset for calibrating DSSAT crop growth models. In DSSAT v3, vol. 4. (G. Hoogenboom, P. W. Wilkens and G. Y. Tsuji ed.), pp. 217-283. University of Hawaaii, Honolulu, Hawaii .

Peter G. A. and Mayne B. C. (1974). The Azolla-Anabaena azollae relationship. II. Localization of nitrogenase activity as assayed by acetylene reduction. Pl. Physiol. 58: 820-835.

Peter G. A., Toia jr R. E., Evans W. R., Crist D. K., Mayne B. C. and Poole R. E (1980). Characterization and comparison of five $\mathrm{N}_{2}$ - fixing $\mathrm{N}_{2}$ Azolla-Anabaena associations. 1. Optimization of growth conditions for biomass increase and $\mathrm{N}$ content in a controlled environment. Pl. Cell Envir. 3: 261-269.

Ramesh K. and Chandrasekaran B. (2004). Soil organic carbon bulk-up and dynamics in rice-rice cropping systems. J. Agron. Crop Sci. 190: 21-27.

Thomas G. W. (1982). Exchangeable Cations. In Methods of Soil Analysis. (A. L. Page, R. H. Miller and D. R. Keeney, ed.), pp. 159-165. Part 2-Chemical and Microbiological Properties.

Walkley A. and Black I. A. (1934). An examination of the different methods for determining soil organic matter and a proposed modification of the chromic acid titration method. Soil Sci. 37: 29-38.

Watanabe F. S. and Olsen E. R. (1965). Test of an ascorbic method for determining phophorus in water and $\mathrm{NaHCO}_{3}$ extract from soil. Soil Sci. Am. Proc. 29: 677-678.

Watanabe I., Espinas C. R., Berja N. S. and Alimagno B. V. (1977). Utilization of Azolla - Anabaena complex as a nitrogen source. International Rice Research Newsletter. 30 pp.

\author{
Appendix 1 \\ Composition of culture solution for growth of symbiotic Azolla.
}

$\begin{array}{lcl}\text { Element } & \text { Conc (p.p.m.) } & \text { Reagent } \\ \mathrm{P} & 20 & \mathrm{NaH}_{2} \mathrm{PO}_{4} \cdot \mathrm{H}_{2} \mathrm{O} \\ \mathrm{K} & 40 & \mathrm{~K}_{2} \mathrm{SO}_{4} \\ \mathrm{Ca} & 40 & \mathrm{CaCl}_{2} \cdot 2 \mathrm{H}_{2} \mathrm{O} \\ \mathrm{Mg} & 40 & \mathrm{MgSO}_{4} \cdot 7 \mathrm{H}_{2} \mathrm{O} \\ \mathrm{Fe} & 0.5 & \mathrm{Fe} \mathrm{EDTA}_{2} \\ \mathrm{Mn} & 0.5 & \mathrm{NaMoO}_{4} \cdot 2 \mathrm{H}_{2} \mathrm{O} \\ \mathrm{B} & 0.20 & \mathrm{H}_{3} \mathrm{BO}_{3} \\ \mathrm{Zn} & 0.01 & \mathrm{ZnSO}_{4} \cdot 7 \mathrm{H}_{2} \mathrm{O} \\ \mathrm{Cu} & 0.01 & \mathrm{CuSO}_{4} \cdot 5 \mathrm{H}_{2} \mathrm{O} \\ \mathrm{Co} & 0.01 & \mathrm{CoC}_{12} \cdot 6 \mathrm{H}_{2} \mathrm{O}\end{array}$

West African Journal of Applied Ecology - Volume 13 
(2/5 of Hoagland's N-free medium)

West African Journal of Applied Ecology - Volume 13 


\section{INSTRUCTIONS TO AUTHORS}

Papers for submission to the West African Journal of Applied Ecology should be written in English and should not exceed 8,000 words in total length. Papers should not have been submitted or be considered for submission for publication elsewhere. Ideas expressed in papers that are published in the Journal are entirely those of the authors and not those of the Editors. Papers submitted will be subjected to peer review before possible publication. Authors are encouraged to suggest names of two potential referees. They should, however, not be from the same Institute, nor should they have been at any time closely associated professionally with the author(s) of the paper being submitted. The Editorial Board regards these names as suggestions only, and is not obliged to use any or both of the proposed names.

Papers for publication should be submitted to:

The Editor

West African Journal of Applied Ecology

Ecological Laboratory Unit

University of Ghana

P. O. Box LG59

Legon, Accra

Ghana.

\section{Reprints}

Authors will receive one copy of the Journal in which their papers are published. Author(s) may order reprints at their own cost. Proofs come to the authors with reprints order forms.

\section{Copyright}

Authors publish in the Journal with the understanding that they assign their copyright to the West Africa Journal of Applied Ecology.

\section{Organization of Manuscripts}

Authors should please submit three copies of their manuscript, typed with double spacing, including figure legends, table footnotes and references, on one side of A4 $(30 \mathrm{~cm} \times 21 \mathrm{~cm})$ size high quality paper, with $2.5 \mathrm{~cm}$ margins on all four sides. Papers must be numbered sequentially, including the abstract, figure legends and tables. The paper should be organised into the following sections:

- Title page, indicating title, short running title, name of each author, and, for each author, position held and full address. Please, indicate which address should be used for correspondence and reprints requests where there is more than one author.

- Abstract, not exceeding 300 words. Should provide a brief summary of the basic content of the paper, including major methods used, results and deductions or conclusions. Avoid abbreviations and do not include tables and diagrams, and, unless absolutely necessary, references should be excluded.

- Introduction, to supply background information and references of earlier published reports related to the study, and provide the rationale for undertaking the study. Should avoid excessive references, particularly those not closely related to the study.

- Materials and methods, to provide sufficient technical information on approaches, materials and equipment, etc., used to obtain the results reported, such that the work could be duplicated by someone else.

- Results, reporting only the results of the experiments, illustrated by Tables and Figures.

- Discussion, an interpretation of the results, and its relation to other previously published work on the subject, and must not be a recapitulation of results.

West African Journal of Applied Ecology - Volume 13 
- Acknowledgement, indicating the source of any financial support or personal assistance received in carrying out the study.

- References, listing all quoted published material, arranged in alphabetical order, typed double-space. Abbreviate journal names according to BIOSIS Serial Sources (Bio-Sciences Information Service, Philadelphia, Pa., 1997).

Follow the styles shown in the examples below:

Bhuvaneswari T. V. and Selheim B. (1985). Root hair deformation in the white clover/Rhizobium trifolii, symbiosis. Physiol. Plant. 63: 25-34.

Deutscher M. P. (1990). Guide to Protein Purification. Academic Press Inc., San Diego, USA.

Dreyfs B., Garcia J. L. and Gillis M. (1988). Characterization of Azorhizo-bium caulinodans gen. Nov., sp. Nov., a stem-nodulating nitrogen-fixing bacterium isolated from Sesbania rostrata. Int. J. Syst. Bacteriol. 38: 89-98.

Van Rhee J. E. (1963). Earthworm activities and the breakdown of organic matter. In Soil Organisms. (J. Doeksen and J. van der Drift, ed.), pp. 55-59. North Holland, Amsterdam.

Sambrook J., Fritsch E. F. and Maniatis T. (1989). Molecular Cloning: A Laboratory Manual. Cold Spring Harbor Laboratory, Cold Spring Harbor, New York, USA.

References in the text should be quoted by the author's name and date in parenthesis and presented in date order. Where there are more than two authors, the first author only should be quoted, followed by et al. and date in parenthesis.

Illustrations and Tables, should be of high quality, and line drawing. Should be in a form suitable for reproduction without modification. Figures, photographs and tables should be added separately, i.e. not inserted in the typed text, with each figure or table presented on a separate page, and designed for linear reduction in the ratio of $2: 1$ or $3: 2$, for printing within a column width of $6.5 \mathrm{~cm}$ or a double-column width of $13.6 \mathrm{~cm}$. Lettering on axes and within figures should be clear and big enough to be legible even upon 50-75\% reduction in size. The figure legends should be typed, correspondingly, on a separate page, headed Legends, at the end of the article. The author's name, the figure number and indication of its proper orientation should be written lightly on the back of each figure. Photographs should be supplied as black-and-white, high contrast glossy prints. Colour plates may be inserted only if author agrees to pay for the expenses involved.

\section{Units}

All measures should be indicated in SI units. Where necessary they may be followed by the equivalent in traditional units in parenthesis.

\section{Change of Address}

Authors should promptly notify the Editor of any change of address.

\section{Reviews of Books}

Books and monographs will be reviewed by invited reviewers. They may be sent to the Editor.

\section{Notes to Authors}

- Copyright material. Authors have the responsibility of ensuring that co-authors are in agreement with the form and submission of the manuscript, and for obtaining permission to quote material from copyright sources. 
- Returning of manuscripts to authors. Manuscripts submitted will not be returned to authors unless specifically requested at the time of submission.

- Proofs will be sent to authors for final correction. However, authors are not expected to make extensive modifications of manuscripts at this stage, otherwise they would be surcharged. Proofs sent to authors for correction should be returned within a week of receipt, together with any order for reprints.

- Acceptance of manuscripts for publication. Acceptance of a manuscript for publication will be indicated explicitly in a letter to the author, and whether any corrections or modifications are required to be made on the paper or not. Similarly, authors whose papers are rejected for publication will be notified. 